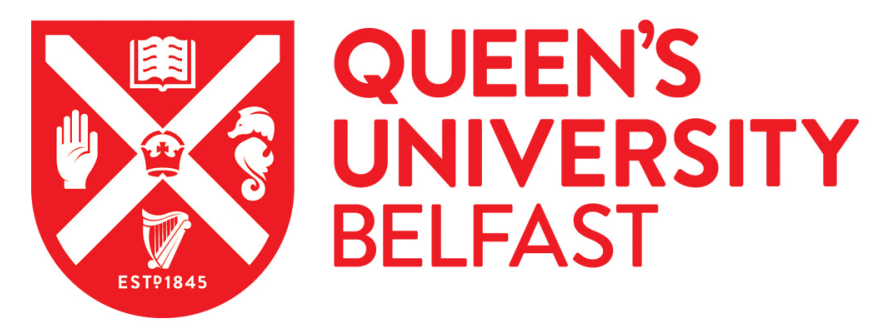

\title{
A comparison of total-mixed-ration and feed-to-yield strategies on blood profiles and dairy cow health.
}

Little, M., Arnott, G., Welsh, M., Barley, J. P., O'Connell, N., \& Ferris, C. (2018). A comparison of total-mixedration and feed-to-yield strategies on blood profiles and dairy cow health. Veterinary Record. https://doi.org/10.1136/vr.104781

Published in:

Veterinary Record

Document Version:

Peer reviewed version

Queen's University Belfast - Research Portal:

Link to publication record in Queen's University Belfast Research Portal

Publisher rights

Copyright $2018 \mathrm{BMJ}$. This work is made available online in accordance with the publisher's policies. Please refer to any applicable terms of use of the publisher.

\section{General rights}

Copyright for the publications made accessible via the Queen's University Belfast Research Portal is retained by the author(s) and / or other copyright owners and it is a condition of accessing these publications that users recognise and abide by the legal requirements associated with these rights.

Take down policy

The Research Portal is Queen's institutional repository that provides access to Queen's research output. Every effort has been made to ensure that content in the Research Portal does not infringe any person's rights, or applicable UK laws. If you discover content in the Research Portal that you believe breaches copyright or violates any law, please contact openaccess@qub.ac.uk. 


\section{A comparison of total-mixed-ration and feed-to-yield strategies on blood profiles and}

\section{2 dairy cow health}

3

4 M. W. Little ${ }^{1,2}$ G. A. Arnott, ${ }^{2}$ M. D. Welsh, ${ }^{3}$ J. Barley, ${ }^{3}$ N. E. O'Connell, ${ }^{2}$ and C. P. Ferris ${ }^{1}$

$6{ }^{1}$ Agri-Food and Biosciences Institute, Sustainable Agri-Food Sciences Division, Large Park, 7 Hillsborough, County Down BT26 6DR, United Kingdom.

$8 \quad{ }^{2}$ Institute for Global Food Security, Queens University Belfast, Northern Ireland Technology

9 Centre, Malone Road, Belfast BT9 5HN

$10{ }^{3}$ Agri-Food and Biosciences Institute, Veterinary Sciences Division, Stoney Road, Belfast 11 BT4 3SD, United Kingdom.

13 Corresponding author:

14 Mark Little; markwlittle@me.com

\section{ABSTRACT}

19 Seventy-two Holstein-Friesian dairy cows were offered the same amount of concentrates over

20 the first 140-days of lactation, by either a 'total-mixed-ration' or a 'feed-to-yield' strategy.

21 The effects on blood profiles and cow health were examined. Cows on total-mixed-ration were offered a mixed ration comprising grass silage and concentrates (50:50 dry matter basis). Cows on feed-to-yield were offered a basal mixed ration (grass silage plus $6 \mathrm{~kg}$

24 concentrates/cow/day) plus additional concentrates via an out-of-parlour feeding system,

25 calculated according to each individual cow's milk yield during the previous week. Cows on 
total-mixed-ration had a higher mean haemoglobin, packed cell volume and lymphocyte percentage. Concentrate allocation strategy had no effect on serum haptoglobin concentrations, interferon gamma production of pokeweed mitogen stimulated whole blood culture, the incidence of clinical or subclinical mastitis, lameness, respiratory or digestive problems, and no strong relationships were identified between production parameters with serum metabolites, inflammatory and immune measures. This study demonstrates small physiological differences in metabolic parameters, and no differences in inflammatory or immune parameters, when allocating concentrates by total-mixed-ration or feed-to-yield.

\section{INTRODUCTION}

Genetic selection for milk production over many decades has led to the development of today's high yielding dairy cow (Ingvartsen and Moyes, 2013). During early lactation the energy demands of these higher yielding cows normally outpace intakes (Bell, 1995), resulting in negative energy balance (EB) and adipose tissue mobilisation to meet the energy shortfall (Grummer et al., 2004; Ingvartsen, 2006). Negative EB can be detrimental to dairy cow immunity (Ingvartsen and Moyes, 2013; LeBlanc, 2014) resulting in higher incidences of diseases such as mastitis (Søndergaard et al., 2002). Multiple immune cell changes have been characterised during negative EB, including reduced neutrophil function (Kehrli et al., 1989; Burvenich et al., 2007) and reduced lymphocyte function (Nonnecke et al., 2003; Lessard et al., 2004; Lacetera et al., 2005). In addition, metabolic profiles associated with negative EB, such as low blood glucose and high non-esterified fatty acid (NEFA) and $\beta$ hydroxybutyrate (BHB) concentrations, have been shown to contribute to immune suppression in in-vitro studies (Newsholme et al., 1986; Suriyasathaporn et al., 2000; Scalia et al., 2006). 
51 The adoption of nutritional and management strategies that reduce early lactation negative

52 EB may reduce the risk of health problems (Ingvartsen et al., 2003; Ingvartsen, 2006). For example, once-a-day milking in early lactation has been shown to reduce serum NEFA concentrations compared with milking three times a day (Patton et al., 2006). It has also been suggested that improving dry matter (DM) intake (DMI) in early lactation to better meet energy requirements may reduce metabolic stress (Ingvartsen, 2006). Strategies by which this might be achieved include; improving volatile fatty acid (VFA) absorption capacity in the rumen thereby reducing VFA accumulation and increasing rumen $\mathrm{pH}$ (Dirksen et al., 1985); increasing diet digestibility and rate of passage (Ingvartsen, 2006); and offering high quality

60 forages and increased concentrate levels (Ferris et al., 2003). It is also possible that the 61 adoption of 'precision' feed-to-yield concentrate allocation strategies, which target concentrates to meet individual cow energy requirements (rather than a 'herd-based' totalmixed-ration approach), may reduce the extent of negative EB experienced by individual cows.

66 A number of studies have compared these two concentrate allocation strategies, with performance largely unaffected by allocation strategy (Taylor and Leaver, 1984a, b; Lawrence et al., 2015; Purcell et al., 2016). However, across these studies the impact of concentrate allocation strategy on cow health, blood metabolites and immune function has received little attention. To address this issue, this paper examines the metabolic,

71 inflammatory and immune profiles, and health of dairy cows during first 140-days of lactation when allocated the same amount of concentrates by two different strategies, namely 'feed-to-yield' or as a 'total-mixed-ration'. While a detailed description of milk production,

74 tissue changes and fertility of the cows on this study has already been presented by Little et al. (2016), the key performance parameters are summarised in this paper. 
Animals and Housing

This study involved 77 multiparous (mean parity, 3.2; SEM, 0.17; median parity 3.0) Holstein-Friesian dairy cows. Cows had a mean Predicted Transmitting Ability (PTA2015) for milk yield and fat plus protein yield of 247 (SEM, 29.1) $\mathrm{kg}$ and 30 (SEM, 4.5) $\mathrm{kg}$, respectively, and were within the top $1 \%$ of UK genetics in terms of Profitable Lifetime Index (PLI 2014), namely $£ 179$ (SEM, 21.1). All procedures described in this paper were conducted under an experimental license granted by the Department of Health, Social Services \& Personal Safety for Northern Ireland, in compliance with the United Kingdom (UK) Animals (Scientific Procedures) Act 1986.

86

Throughout the experiment, cows were housed together in a free stall cubicle house with concrete flooring, which was scraped every three hours by an automated system. The cubicle to cow ratio was $\geq 1: 1$ at all times and cubicles were fitted with rubber mats and bedded 90 thrice weekly with sawdust.

91

\section{Experimental Design, Diets and Feeding}

All cows were managed identically during the prepartum period. Within 24-hours of calving, cows were transferred from a maternity pen to the free stall cubicle house and allocated by simple randomization to one of two concentrate allocation strategies, either 'feed-to-yield' or 'total-mixed-ration'. Throughout the allocation process, visual checks was made to ensure that the two treatment groups remained balanced for expected calving date, parity, previous lactation 305-day milk yield, body weight (BW) and body condition score (BCS) at previous lactation drying off, PTA for fat plus protein $(\mathrm{kg})$, and number of services and calving

100 interval during the previous lactation. With each concentrate allocation strategy, the objective 
101 was to achieve the same total concentrate intake over a 20 -week period and therefore rations were designed to be nitrogenous.

104 Cows on total-mixed-ration were offered a mixed ration comprising grass silage and 105 concentrates (fixed for the study at 50:50 DM ratio). Chopped straw was included in the mix 106 to achieve a target intake of $0.3 \mathrm{~kg} / \mathrm{cow} / \mathrm{day}$. This ration was designed to meet maintenance energy requirements and support a mean milk yield of $40 \mathrm{~kg} / \mathrm{cow} / \mathrm{day}$, assuming an average BW loss of $0.5 \mathrm{~kg} / \mathrm{cow} /$ day, over the 20 -week study. Ration formulation was based on the equations contained within 'Feed into Milk' (Agnew et al., 2004), the current UK dairy cow

110 feed rationing system, and the metabolisable energy (ME) and intake potential of the grass

111 silage, as determined by near-infrared reflectance spectroscopy (NIRS).

113 Cows on feed-to-yield were offered a basal mixed ration ad libitum, comprising grass silage 114 plus concentrates, the latter included to achieve an average intake of $6.0 \mathrm{~kg}$ 115 concentrate/cow/day. Chopped straw was included in the mix to achieve a target intake of 0.3 $116 \mathrm{~kg} / \mathrm{cow} / \mathrm{day}$. Based on the equations of Agnew et al. (2004), and the estimated intake 117 potential and nutritive value of the silage offered, this 'basal ration' was initially estimated to 118 sustain the maintenance energy requirements of the cow plus a milk yield of $27 \mathrm{~kg} / \mathrm{cow} / \mathrm{day}$, 119 which was revised to $24 \mathrm{~kg} / \mathrm{cow} /$ day based on actual DMI data. In addition to this basal 120 ration, cows on feed-to-yield were offered additional concentrates via an out-of-parlour 121 feeding system (Fullwood Ltd, Shropshire, England). From day-1 postpartum, these 122 additional concentrates were increased in $0.25 \mathrm{~kg} /$ day increments, so that cows were offered $1235.25 \mathrm{~kg} /$ day at day-21. From day-21 onwards, concentrate feed levels were adjusted weekly 124 based on the mean milk yield during the previous 7-day period, with concentrates offered at $1250.45 \mathrm{~kg}$ for each $\mathrm{kg}$ of milk produced above what the basal diet was assumed to sustain. To 
maintain efficient cow flow into the parlour, all cows on were offered an additional $0.5 \mathrm{~kg}$ concentrate per milking via an in-parlour feeding system.

A common concentrate was offered with both treatments. The concentrate offered mixed

130 with the silage was in the form of a meal, while the concentrate offered via the in-parlour and 131 out-of-parlour feeding system was in the form of a pellet. The ingredient composition of the concentrate offered (g/kg fresh basis) was as follows: maize, 215.5; wheat, 160; wheat feed, 60; sugar beet pulp, 100; distillers grains, 50; corn gluten, 40; soya hulls, 140; soya bean meal, 80; Sopralin (Trouw Nutrition, Cheshire, UK), 30; rapeseed meal, 40; lime flour, 7; salt, 7.5, calcined magnesite (Trouw Nutrition, Cheshire, UK), 3; Molaferm (United

136 Molasses, Belfast, UK) 50; palm oil, 8; Acid buf (Celtic sea minerals, Cork, Ireland), 8; mineral/vitamin mix (Superdairy, Trouw Nutrition, Cheshire, UK), 4; Actisaf (Lesaffre, Shannon, Ireland), 0.4.

140 Grass silage was produced from a primary growth herbage harvested from predominantly 141 perennial ryegrass-based swards and ensiled following a 24 to 48 hour period of field wilting.

142 Rations were prepared using a complete diet mixer-wagon (Redrock Varicut, Redrock,

143 County Armagh, Northern Ireland) and transferred directly to feed-boxes mounted on weigh 144 cells. Access to treatment rations were controlled by a Calan Broadbent feeding system 145 (American Calan Inc., Northwood, NH, USA) linked to an electronic identification system, 146 thus enabling individual cow intakes to be recorded daily. To ensure ad libitum consumption, 147 the diets for each treatment were offered at $107 \%$ of the previous day's intake. Uneaten 148 ration was removed daily at approximately 08.00 , while the fresh ration was offered between 14909.00 and 10.00. Cows remained on treatments until day-140 of lactation. 
152 Milk samples were obtained once weekly from 2 consecutive milkings (am and pm), a

153 preservative tablet added (Broad Spectrum Microtabs II, D and F Control Systems,

154 Massachusetts, USA), and samples stored at $4^{\circ} \mathrm{C}$ until analyzed. These samples were

155 analyzed weekly for fat, protein and lactose content by fourier transform infrared

156 spectroscopy using an infrared milk analyzer (Milkoscan, model FT 120, Foss UK Ltd.,

157 Warrington, UK) and a weighted milk composition subsequently calculated for each

158 sampling occasion. On 1 occasion each month, samples from 2 consecutive milkings, bulked

159 in proportion to yield, were collected and SCC measured (model CA3A4, Delta Instruments,

160 Netherlands).

161

162 All individual cow health events and treatments were recorded. Cow BW were recorded twice daily (using an automatic weighscale) and cow BCS were recorded weekly using a 1 to 5 scale (Edmonson et al., 1989) with quarter-point increments.

165

166 The mean daily ME requirements and balances for each cow were calculated using the equations of Agnew et al. (2004), where daily mean energy balance (MJ/cow per d) was determined using the equation: mean energy balance $=\left(\left[M E_{\text {main }+ \text { milk }} \times B W^{0.75}\right]+\left[\frac{[0.0013 \times B W]}{K_{m}}\right]-10\right)-M E i$ where $\mathrm{ME}_{\text {main+milk }}$ is the $\mathrm{ME}$ required for maintenance and milk production $(\mathrm{MJ} / \mathrm{kg}$ metabolic 171 weight), $\mathrm{BW}^{0.75}$ is the metabolic $\mathrm{BW}, \mathrm{K}_{\mathrm{m}}$ is the efficiency of utilization of ME for activity 172 (calculated as $0.35 \times \mathrm{ME} /$ gross energy +0.503$)$, and MEi is the ME intake $(\mathrm{MJ} /$ cow per d). 173 Data for mean daily milk yield, milk fat, protein and lactose concentrations, and mean BW 174 were used in the calculations for the energy balance variables. Energy corrected milk yield 175 (ECMY) was calculated using the following formula as defined by Sjaunja et al., (1990); 
176 ECMY $(\mathrm{kg} / \mathrm{cow}$ per $\mathrm{d})=$ milk yield $\mathrm{kg} \times(0.383 \times$ fat $\% \times 0.242 \times$ protein $\%+16.54 \times$

$177 \quad$ lactose $\%+20.7) / 3.140$.

178

\section{Blood Measurements}

180 Blood samples were collected at weeks 2 (11 to 17 days), 4 (25 to 31 days), 6 (39 to 45 days), 8 (53 to 59 days), 10 (67 to 73 days), 12 (81 to 87 days), 16 (109 to 115 days) and 20 (137 to 143 days) of lactation, for the measurement of albumin, BHB, glucose, glutamate dehydrogenase (GLDH), Haptoglobin (Hp), globulin, NEFA, total protein, and urea concentrations. Blood haematology and interferon gamma (IFN- $\gamma$ ) production from stimulated lymphocytes were assessed on a subsample of cows (17 and 20 from total-mixedration and feed-to-yield, respectively), with these sub-groups balanced in the same manner as previously described. Blood samples were stored and analyzed as described by Little et al. (2016).

189

\section{Health, Somatic Cell Count and Vaginal Mucus Score Evaluation}

All individual cow health events and treatments were recorded. Displaced abomasum, dilated cecum, decreased rumen motility and diarrhea were recorded as 'digestive upset'. Abnormal milk and clots were recorded as mastitis. Once a month, samples from two consecutive milkings, bulked in proportion to yield, were collected and SCC measured using mid-infrared diffuse reflectance spectroscopy (model CA3A4, Delta Instruments, Drachten, The Netherlands). Vaginal mucus was clinically scored on both smell and appearance on a 03 scale at weeks 2 (11 to 17 days), 3 (18 to 24 days) and 4 (25 to 31 days) postpartum, according to Little et al. (2016).

199

\section{Statistical Analysis}


Five cows were removed from the experiment for reasons not associated with the treatments and their data excluded from the statistical analysis, leaving 36 cows on each treatment. Data were analyzed using GenStat Version 16.2 (VSN International, Oxford, UK).

Data describing somatic cell score ( $\log ^{\mathrm{e}}$ transformed somatic cell count) were analyzed using ANOVA. Data describing blood measurements were analysed using Residual Maximum Likelihood (REML) repeated measures analysis. The mixed model used included treatment + week + treatment $\times$ week as fixed effects. Cow $\times$ week was included in the random model, to which a power model (city block metric) covariance structure was applied. Individual cow data was used to investigate relationships between EB and ECMY, and each of NEFA, BHB,

210 glucose, WCC, neutrophil \%, lymphocyte $\%$, IFN- $\gamma$ and Hp, using simple linear regression 211 analysis. Best fit equations (either a common or different equation for both treatments) were identified. Analysis was initially undertaken using mean data for the entire study, and also using the mean data for weeks 6 to 10 postpartum, the period encompassing peak milk yield.

214 Relationships between NEFA, BHB and glucose, and each of IFN- $\gamma$ and Hp were 215 investigated in the same way. Differences were considered to be statistically significant when

$216 \mathrm{P}<0.05$. Binomial data describing health treatments were analysed using generalised linear model regression analysis with the logit link function. The model included treatment as a term and significance was identified using chi squared. Data describing vaginal mucus scores were analysed using ordinal logistic regression with the logit link function and significance was identified using chi squared. Vaginal mucus scores were translated into one integer; $0=$ categories, $0,1, \geq 2$. 
The chemical composition of the grass silage and concentrate offered is presented in Table 1.

The total rations offered with the feed-to-yield and total-mixed-ration treatments had a mean ME of 11.4 and $11.4 \mathrm{MJ} / \mathrm{kg} \mathrm{DM}$, respectively, a mean $\mathrm{CP}$ of 170 and $170 \mathrm{~g} / \mathrm{kg} \mathrm{DM}$, respectively, a mean starch content of 154 and $150 \mathrm{~g} / \mathrm{kg} \mathrm{DM}$, respectively, and a mean NDF of 389 and $391 \mathrm{~g} / \mathrm{kg}$, respectively. A summary of a number of the main cow performance parameters, as reported previously by Little et al. (2016), is presented in Table 2. Concentrate allocation strategy had no effect $(\mathrm{P}>0.05)$ on total DMI, concentrate DMI, milk yield, milk fat or milk protein composition, milk fat plus protein yield, mean BW, BW loss to nadir and mean EB (Table 2). Concentrate allocation strategy had no effect $(\mathrm{P}>0.05)$ on mean serum glucose, BHB, albumin, globulin, total protein, urea, GLDH, red cell count (RCC), white cell count (WCC), Hp or IFN- $\gamma$ production (Table 3). Mean corpuscular volume (51.3 and $50.4 \mathrm{fL}$ for total-mixed-ration and feed-to-yield, respectively: $\mathrm{SED}=1.03, \mathrm{P}=0.538$ ), mean corpuscular haemoglobin (16.5 and 16.2 pg for total-mixed-ration and feed-to-yield, respectively: SED = $0.30, \mathrm{P}=0.151)$, and mean corpuscular haemoglobin concentration $(32.3$ and $32.1 \mathrm{~g} / 100 \mathrm{~mL}$

240 for total-mixed-ration and feed-to-yield, respectively: $\mathrm{SED}=0.27, \mathrm{P}=0.700$ ), were unaffected by treatment. Cows on total-mixed-ration had a higher haemoglobin $(P=0.009)$, packed cell volume $(\mathrm{PCV})(\mathrm{P}=0.018)$, and lymphocyte \% $(\mathrm{P}=0.020)$, and had a lower serum NEFA $(\mathrm{P}=0.028)$ and neutrophil \% $(\mathrm{P}=0.018)$ than cows on feed-to-yield (Table 3$).$

244 Serum NEFA $(\mathrm{P}<0.001)$, BHB $(\mathrm{P}<0.001)$, white cell count $(\mathrm{P}<0.001)$ and neutrophil \% $(\mathrm{P}$ $245=0.008)$ decreased with time, while glucose $(\mathrm{P}<0.001)$, albumin $(\mathrm{P}=0.002)$, total protein $(\mathrm{P}$ $<0.001)$, urea $(\mathrm{P}<0.001)$, GLDH $(\mathrm{P}=0.019)$, and lymphocyte \% $(\mathrm{P}=0.020)$ increased with time (Table 3. The effect of concentrate allocation strategy on mean NEFA and BHB (Figure

248 1), mean blood lymphocyte and neutrophil percentage (Figure 2) and mean serum Hp and 249 IGN- $\gamma$ production (Figure 3), over the experimental period, are presented. 

biochemistry, haematology and immune parameters are presented. Using mean data over the study period, the relationship between EB and NEFA was described by separate equations for each treatment $\left(\mathrm{R}^{2}=0.196, \mathrm{P}<0.001\right)$, while the relationship between EB and WCC was described by a common equation $\left(\mathrm{R}^{2}=0.258, \mathrm{P}<0.001\right)$ for each treatment (Table 4). Using mean data for weeks 6 to 10 postpartum, the relationships between EB and NEFA $\left(\mathrm{R}^{2}=\right.$ 0.194, $\mathrm{P}=0.005), \mathrm{EB}$ and $\mathrm{BHB}\left(\mathrm{R}^{2}=0.071, \mathrm{P}=0.013\right)$, and $\mathrm{EB}$ and $\mathrm{WCC}\left(\mathrm{R}^{2}=0.297, \mathrm{P}<\right.$ 0.001) were described by common equations for each treatment (Table 4). Using mean data over the study period, the relationships between ECMY and NEFA $\left(\mathrm{R}^{2}=0.169, \mathrm{P}<0.015\right)$, and ECMY and BHB $\left(\mathrm{R}^{2}=0.050, \mathrm{P}<0.033\right)$ were described by common equations for each treatment, while the relationship between ECMY and WCC $\left(\mathrm{R}^{2}=0.179, \mathrm{P}<0.013\right)$ was described by a separate equation for each treatment (Table 5). Using mean data for weeks 6 to 10 postpartum, the relationships between ECMY and BHB $\left(\mathrm{R}^{2}=0.178, \mathrm{P}=0.005\right)$ and ECMY and WCC $\left(\mathrm{R}^{2}=0.234, \mathrm{P}<0.001\right)$ were described by separate equations for each treatment (Table 5). Using data for week 6 to 10 postpartum, the relationship between IFN- $\gamma$ production and $\mathrm{BHB}(\mathrm{r}=0.32, \mathrm{P}=0.031)$ was described by a common equation. Concentrate allocation strategy had no effect $(P>0.05)$ on the probability of obtaining different vaginal mucus scores at weeks 2, 3 and 4 postpartum (Table 6). mastitis, lameness, respiratory problems, digestive problems or on mean Somatic Cell Scores (Table 7).

\section{DISCUSSION}

Many concentrate allocation strategies are adopted on dairy farms, from total-mixed-rations

274 that are designed to meet the average nutrient requirements of a group of cows and rely on 
275 DMI variation to meet nutritive requirements; to more precise feed-to-yield strategies that 276 tailor concentrate allocations according to the milk yield of individual cows. This study was

277 designed to examine the effects of allocating similar amounts of concentrates over a 20-week 278 period by two very different strategies, 'feed-to-yield' and 'total-mixed-ration', on the 279 metabolic, inflammatory and immune profiles of dairy cows. As previously reported by Little 280 et al. (2016), cows on feed-to-yield tended to lose more BW to nadir than cows on total281 mixed-ration.

283 Although cows on feed-to-yield had a higher NEFA than total-mixed-ration cows, the actual 284 difference of $0.04 \mathrm{meq} / \mathrm{L}$ is physiologically small. This agrees with the absence of differences 285 between treatments in BHB and GLDH, (both of which can increase during tissue mobilization; Bell, 1995; Herdt, 2000; Otter, 2013), and the fact that treatment had no effect on mean DMI, milk yield or mean EB. Similarly, Lawrence et al. (2015) found no strong evidence for differences in tissue mobilization between cows managed on different concentrate allocation strategies. Although concentrate allocation strategy resulted in 290 significant treatment $\times$ time interactions for concentrate DMI and milk yield (Little et al., 2016), this was not reflected in significant treatment $\times$ time interactions for the biochemistry parameters examined, which highlights that the cows were able to maintain homeorhesis (Bauman and Currie, 1980). In common with other studies (Nyman et al., 2008; Mendonça et al., 2014; McCarthy et al., 2015), NEFA declined over the study period, indicative of a decreasing rate of tissue mobilisation as lactation proceeded. The absence of a treatment $x$ week interaction for NEFA suggests that tissue mobilisation did not differ between treatments with stage of lactation, consistent with a lack of treatment $\times$ time interactions for cow performance data (Little et al., 2016). 
300 A key objective was to examine if individual animals within each treatment experience

301 differences in metabolic stress. For example, with feed-to-yield, higher yielding cows are

302 allocated additional concentrates, which tends to drive higher milk yields (Little et al., 2016)

303 and this may cause metabolic stress. Little et al. (2016) previously demonstrated that while

304 negative EB increased with increasing milk yields, this was more pronounced with cows on

305 feed-to-yield. In the current study, the relationship between EB and NEFA over the study

306 period are described by parallel lines for each treatment, indicating similar responses from

307 cows on each treatments. However, the higher intercept with cows on feed-to-yield indicates

308 a lesser degree of metabolic stress at higher yields compared to cows offered the total-mixed-

309 ration. As common equations described the relationships between EB and NEFA, and EB and

310 BHB between weeks 6 to 10 of lactation, the differences in metabolic stress between

311 treatments was not evident during peak yield

312

313 While cows on total-mixed-ration had a higher PCV and haemoglobin compared to those on

314 feed-to-yield, the differences are physiologically small and within normal reference ranges

315 (Radostits et al., 2007). In addition, the absence of differences in RCC, mean corpuscular

316 volume, mean corpuscular haemoglobin and mean corpuscular haemoglobin concentration

317 suggest a negligible difference in red blood cell function between treatments. The decrease in

318 WCC and neutrophil percentage with time from calving is consistent with the findings of

319 others (Kehrli et al., 1989; Meglia et al., 2001), while the absence of any significant treatment

$320 \times$ time interactions indicate that treatments did not produce a different response in these

321 variables. There was a positive relationship between EB and WCC, and a negative

322 relationship between ECMY and WCC. The former agrees with Morris et al. (2009), who

323 found that a lower WCC in cows with a severe negative EB compared with those with a mild 
negative EB. As these relationships are described by common equations for both treatments, concentrate allocation strategies did not affect WCC response.

327 The impact of concentrate allocation strategy on inflammatory and immune profiles has not 328 previously been examined. Serum $\mathrm{Hp}$ was used as an indirect measure of clinical and subclinical inflammatory, infectious and metabolic conditions. That mean Hp was unaffected by treatment suggests similar levels of inflammation with both treatments. The absence of a stage of lactation effect, or a treatment $\mathrm{x}$ time interaction, demonstrates that the different DMI and milk yield curves for each treatment, as presented by Little et al. (2016), did not lead to differences in $\mathrm{Hp}$ concentrations. The absence of significant relationships between $\mathrm{Hp}$ concentrations and either EB or ECM, demonstrate that the extremes of concentrate intakes and milk yields with feed-to-yield did not influence the inflammatory status of individual animals. In addition, an increase in total WCC (leukocytosis) or neutrophil percentage (neutrophilia), and a decrease in lymphocyte percentage (lymphopenia), occur as part of inflammatory responses during periods of stress (Cole, 1997; Otter, 2013). Cows on feed-toyield had a higher neutrophil percentage and lower lymphocyte percentage compared with cows on total-mixed-ration, suggestive of a degree of inflammatory stress. However, as neutrophil values remained within normal physiological ranges, these changes cannot be defined as neutrophilia, as occurs in a true stress leukogram (Radostits et al., 2007). No significant relationships were identified between either EB or ECMY, and neutrophil or lymphocyte percentages, suggesting metabolic stress or production does not affect while blood cell parameters.

347 Interferon gamma is a cytokine synthesised by activated T-lymphocytes, which functions to 348 enhance immune surveillance and activate the cellular immune response during infection 
349 (Young and Hardy, 1995; Schroder et al., 2004). Concentrate allocation strategy had no effect on the ability of lymphocytes to produce IFN- $\gamma$, while IFN- $\gamma$ production did not change over

351 time, nor was there an interaction between treatment or stage of lactation. Previous studies

352 have shown that higher NEFA concentrations can have a suppressive effect on IFN- $\gamma$ 353 production (Lacetera et al., 2004; Ster et al., 2012), while management strategies imposed to 354 reduce metabolic stress have been shown to mitigate the normal decrease in IFN- $\gamma$ around calving (Loiselle et al., 2009). In this study, while serum NEFA were significantly lower with cows on total-mixed-ration, the magnitude of this difference $(0.04 \mathrm{meq} / \mathrm{L})$ was not sufficient to impact IFN- $\gamma$ production. The lack of significant relationships between IFN- $\gamma$ production and either EB or ECMY, suggests the larger range of EB and individual cow milk yields with the feed-to-yield treatment had no effect on immune function.

361 While most diseases in dairy cows have a multifactorial aetiology, the cow's ability to defend against infectious disease is in-part related to the efficiency of the immune system.

363 Concentrate allocation strategy had no effect on somatic cell score or clinical mastitis 364 incidence, suggesting that the udder defence to contagious and environmental organisms were unaffected by treatment. While the aetiology of lameness is multifactorial, with complex interactions between nutritional, metabolic, environmental and infectious risk factors (Alban, 1995; Solano et al., 2015), the efficacy of the immune response to infectious organisms can

368 play a role in disease susceptibility (Palmer and O'Connell, 2015). Nevertheless, the current 369 study demonstrates no impact of concentrate allocation strategy on the incidence of lameness. 370 An effective immune response is also important in resolving the normal and unavoidable 371 uterine bacterial contamination after calving, therefore helping to prevent against the 372 development of clinical uterine disease (Sheldon et al., 2008; Sheldon et al., 2009). Vaginal 373 mucus scores provided an indirect assessment of uterine bacterial infection and inflammation 
374 (Williams et al., 2005). As there was no significant difference in vaginal mucus scores at weeks 2,3 and 4 postpartum, this suggests that the concentrate allocation strategies did not significantly influence the immunological response to the inevitable uterine contamination in the early postpartum period, in keeping with the similar inflammatory and immune responses.

Digestive upsets in dairy cows are largely due to dietary factors rather than infectious causes. In the current study, concentrate allocation strategy had no significant effect on digestive upsets, which is in keeping with this the previous findings of no effect of concentrate allocation strategy on faecal consistency scores (Little et al., 2016),

\section{CONCLUSION}

When concentrates were allocated to dairy cows on either a feed-to-yield or a total-mixedration basis, health, inflammatory and immune profiles were unaffected. While concentrate allocation strategy had a number of minor effects on haematology and biochemistry profiles, these had negligible physiological consequences. No strong relationships were identified between production variables, and biochemistry, haematology, inflammatory and immune variables, and these did not greatly differ with concentrate allocation strategy.

This study was co-funded by the Department of Agriculture, Environment and Rural Affairs for Northern Ireland and by AgriSearch (Northern Ireland farmer levy). Thanks are due to the Dairy Unit staff at the AFBI Hillsborough for care of the experimental animals and for assisting with experimental measurements, the laboratory staff in AFBI Hillsborough for undertaking milk and feed analysis, and to the staff in AFBI Veterinary Sciences Division for 
assisting with immune function analysis. Mark Little acknowledges the receipt of a $\mathrm{PhD}$

400

401

402

403

404

405

406

407

408

409

410

411

412

413

414

415

416

417

418

419

420

421

422

423

424

425

426

427

428

429

430

431

432

433

434

435

436

437

438

439

440

441

442

443

444

studentship from AgriSearch.

\section{REFERENCES}

AGNEW, R. E., YAN, T., FRANCE, J., KEBREAB, E., \& THOMAS, C. (2004) Energy requirement and Supply. Pages 11-20 in Feed into Milk. A new applied feeding system for dairy cows. 1st ed. Nottingham University Press, Nottingham.

ALBAN, L. 1995. Lameness in Danish dairy cows: frequency and possible risk factors. Preventative Veerinary Medicine 22, 213-225

BAUMAN, D. E. \& CURRIE, B. W. (1980) Partitioning of nutrients during pregnancy and lactation: A review of mechanisms involving homeostasis and homeorhesis. Journal of Dairy Science 63, 1514-1529

BELL, A. W. (1995) Regulation of organic nutrient metabolism during transition from late pregnancy to early lactation. Journal of Animal Science 73, 2804-2819

BURVENICH, C., BANNERMAN, D. D., LIPPOLIS, J. D., PEELMAN, L., NONNECKE, B. J., KEHRLI JR, M. E., \& PAAPE, M. J. (2007) Cumulative physiological events influence the inflammatory response of the bovine udder to Escherichia coli infections during the transition period 1. Journal of Dairy Science 90, Supplement(0):E39-E54

COLE, D. J., ROUSSEL, A. J., \& WHITNEY, M. S. (1997) Interpreting a bovine CBC: Evaluating the leukon and acute-phase proteins. Veterinary Medicine 92, 470-478

DIRKSEN, G. U., LIEBICH, H. G., \& MAYER, E. (1985) Adaptive changes of the ruminal mucosa and their functional and clinical significance. Bovine Practitioner 20, 116-120

EARLEY, B. \& CROWE, M. A. (2002) Effects of ketoprofen alone or in combination with local anesthesia during the castration of bull calves on plasma cortisol, immunological, and inflammatory responses. Journal of Animal Science 80, 1044-1052

EDMONSON, A. J., LEAN, I. J, WEAVER, L. D., FARVER, T., \& WEBSTER, G. (1989) A Body Condition Scoring Chart for Holstein Dairy Cows. Journal of Dairy Science 72, 6878

FERRIS, C. P., GORDON, F. J., PATTERSON, D. C., MAYNE, C. S., \& MCCOY, M. A. (2003) A short-term comparison of the performance of four grassland-based systems of milk production for autumn-calving dairy cows. Grass Forage Science 58, 192-209

FISHER, A. D., CROWE, M. A., O'NUALLÁIN, E. M, MONAGHAN, M. L., LARKIN, J. A., O'KIELY, P., \& ENRIGHT, W. J. (1997) Effects of cortisol on in vitro interferon-gamma production, acute-phase proteins, growth, and feed intake in a calf castration model. Journal of Animal Science 75, 1899-1908 
446 GRUMMER, R. R., MASHEK, D. G, \& HAYIRLI, A. (2004) Dry matter intake and energy balance in the transition period. The veterinary Clinics of North America. Food Animal

HERDT, T. H. (2000) Ruminant adaptation to negative energy balance. Influences on the etiology of ketosis and fatty liver. The Veterinary clinics of North America. Food Animal Practice 16, 215-230

INGVARTSEN, K. L. (2006) Feeding- and management-related diseases in the transition cow: Physiological adaptations around calving and strategies to reduce feeding-related diseases. American Journal of Veterinary Research 126, 175-213

INGVARTSEN, K. L., DEWHURST, R. J., \& FRIGGENS, N. C. (2003) On the relationship between lactational performance and health: is it yield or metabolic imbalance that cause production diseases in dairy cattle? A position paper. Livestock Production Science 83, 277308

Ingvartsen, K. L. and K. Moyes. 2013. Nutrition, immune function and health of dairy cattle. Animal 7, 112-122

KEHRLI JR., M. E., \& HARP J. A. (2001) Immunity in the mammary gland. The veterinary Clinics of North America. Food Animal Practice 17, 495-516

KEHRLI JR., M. E., NONNECKE, B. J., \& ROTH J. A. (1989) Alterations in bovine neutrophil function during the periparturient period. American Journal of Veterinary Research 50, 207-214

LACETERA, N., SCALIA, D., BERNABUCCI, U., RONCHI, B., PIRAZZI, D., \& NARDONE, A. (2005) Lymphocyte functions in overconditioned cows around parturition. Journal of Dairy Science 88, 2010-2016

LACETERA, N., SCALIA, D., FRANCI, O., BERNABUCCI, U., RONCHI, B., \& NARDONE, A. (2004) Short communication: Effects of nonesterified fatty acids on lymphocyte function in dairy heifers. Journal of Dairy Science 87, 1012-1014

LAWRENCE, D. C., O'DONOVAN, M., BOLAND, T. M., LEWIS, E., \& KENNEDY, E. (2015) The effect of concentrate feeding amount and feeding strategy on milk production, dry matter intake, and energy partitioning of autumn-calving Holstein-Friesian cows. Journal of Dairy Science 98, 338-348

LEBLANC, S. J. (2014) Reproductive tract inflammatory disease in postpartum dairy cows. Animal 8, 54-63

LESSARD, M., GAGNON, N., GODSON, D. L., \& PETIT, H. V. (2004) Influence of parturition and diets enriched in $n-3$ or $n-6$ polyunsaturated fatty acids on immune response of dairy cows during the transition period. Journal of Dairy Science 87, 2197-2210

LITTLE, M. W., O'CONNELL, N. E., \& FERRIS, C. P. (2016) A comparison of individual cow versus group concentrate allocation strategies on dry matter intake, milk production, 
tissue changes, and fertility of Holstein-Friesian cows offered a grass silage diet. Journal of Dairy Science 99, 4360 - 4373

LOISELlE, M. C., STER, C., TALBOT, B. G., ZHAO, X., WAGNER, G. F., BOISCLAIR, Y. R., \& LACASSE, P. (2009) Impact of postpartum milking frequency on the immune system and the blood metabolite concentration of dairy cows. Journal of Dairy Science 92, $1900-1912$

MCCARTHY, M. M., MANN, S., NYDAM, D. V., OVERTON, T. R., \& MCART, J. A. A. (2015) Short communication: Concentrations of nonesterified fatty acids and $\beta$ hydroxybutyrate in dairy cows are not well correlated during the transition period. Journal of

MEGLIA, G. E., JOHANNISSON, A., PETERSSON, L., \& WALLER, K. P. (2001) Changes in some blood micronutrients, leukocytes and neutrophil expression of adhesion molecules in periparturient dairy cows. Acta Veterinaria Scandinavica 42, 139-150

MENDONÇA, L. G. D., ABADE, C. C., DA SILVA, E. M., LITHERLAND, N. B., HANSEN, L. B., HANSEN, W. P., \& CHEBEL, R. C. (2014) Comparison of peripartum metabolic status and postpartum health of Holstein and Montbéliarde-sired crossbred dairy cows. Journal of Dairy Science 97, 805-818

MORRIS, D. G., WATERS, S. M., MCCARTHY, S. D., PATTON, J., EARLEY, B., FITZPATRICK, R., MURPHY, J. J., DISKIN, M. G., KENNY, D. A., BRASS, A., \& WATHES, D. C. (2009) Pleiotropic effects of negative energy balance in the postpartum dairy cow on splenic gene expression: repercussions for innate and adaptive immunity. Physiological Genomics 39, 28-37

NEWSHOLME, P., CURI, R., GORDON, S., \& NEWSHOLME, E. A. (1986) Metabolism of glucose, glutamine, long-chain fatty acids and ketone bodies by murine macrophages. Biochemical Journal 239, 121-125

NYMAN, A. K., EMANUELSON, U., HOLTENIUS, K., INGVARTSEN, K. L., LARSEN, T., \& PERSSON WALLER, K. (2008) Metabolites and immune variables associated with somatic cell counts of primiparous dairy cows. Journal of Dairy Science 91, 2996-3009

OTTER, A. (2013) Diagnostic blood biochemistry and haematology in cattle. In Practice 35, $7-16$

PALMER, M. A. \& O'CONNELL N. E. (2015) Digital dermatitis in dairy cows: A review of risk factors and potential sources of between-animal variation in susceptibility. Animals 5(3):512-535

PARK, R. S., AGNEW, R. E., GORDON, F. J., \& STEEN, R. W. J. (1998) The use of near infrared reflectance spectroscopy (NIRS) on undried samples of grass silage to predict chemical composition and digestibility parameters. Animal Feed Science and Technology 72 , $155-167$ 

MURPHY, J. J. (2006) Effect of milking frequency and diet on milk production, energy balance, and reproduction in dairy cows. Journal of Dairy Science. 89, 1478-1487

PURCELL, P. J., LAW, R. A., GORDON, A. W., MCGETTRICK, S. A., \& FERRIS, C. P. (2016) Effect of concentrate feeding method on the performance of dairy cows in early-tomid lactation. Journal of Dairy Science 99, 2811-2824

RADOSTITS, O. M., GAY, C. C., HINCHCLIFF, K. W., \& CONSTABLE, P. D. (2007) Veterinary medicine : a textbook of the diseases of cattle, sheep, pigs, goats and horses. Appendix 2, Reference laboratory values. Edinburgh : Elsevier Saunders, 2007. 10th ed

SCALIA, D., LACETERA, N., BERNABUCCI, U., DEMEYERE, K., DUCHATEAU, L., \& BURVENICH, C. (2006) In vitro effects of nonesterified fatty acids on bovine neutrophils oxidative burst and viability. Journal of Dairy Science 89, 147-154

SCHRODER, K., HERTZOG, P. J., RAVASI, T., \& HUME, D. A. (2004) Interferon- $\gamma$ : an overview of signals, mechanisms and functions. Journal of Leukocyte Biology 75, 163-189

SHELDON, I. M., CRONIN, J., GOETZE, L., DONOFRIO, G., \& SCHUBERTH, H. J. (2009) Defining postpartum uterine disease and the mechanisms of infection and immunity in the female reproductive tract in cattle. Biology of Reproduction 81, 1025-1032

SHELDON, I. M., WILLIAMS, E. J., MILLER, A. N. A., NASH, D. M., \& HERATH, S. (2008) Uterine diseases in cattle after parturition. The Veterinary Journal 176, 115-121

SJAUNJA, L.O., BAEVRE, L., JUNKKARINEN, L., PEDERSEN, J., SETALA, J., (1990): A Nordic proposal for an energy corrected milk (ECM) formula. Performance recording of animals: state of the art 192, 156-157

SOLANO, L., BARKEMA, H. W., PAJOR, E. A., MASON, S., LEBLANC, S. J., ZAFFINO HEYERHOFF, J. C., NASH, C. G. R., HALEY, D. B., VASSEUR, E., PELLERIN, D., RUSHEN, J., DE PASSILLÉ, A. M., \& ORSEL, K. (2015) Prevalence of lameness and associated risk factors in Canadian Holstein-Friesian cows housed in freestall barns. Journal of Dairy Science 98, 6978-6991

SØNDERGAARD, E., SØRENSEN, M. K., MAO, I. L., \& JENSEN, J. (2002) Genetic parameters of production, feed intake, body weight, body composition, and udder health in lactating dairy cows. Livestock Production Science 77, 23-34

STER, C., LOISELLE, M. C., \& LACASSE, P. (2012) Effect of postcalving serum nonesterified fatty acids concentration on the functionality of bovine immune cells. Journal of Dairy Science 95, 708-717

SURIYASATHAPORN, W., HEUER, C., NOORDHUIZEN-STASSEN, E. N., \& SCHUKKEN, Y. H. (2000) Hyperketonemia and the impairment of udder defense: a review. Veterinary Research 31, 397-412 
591 TAYLOR, W. \& LEAVER, J. D. (1984a) Systems of concentrate allocation for dairy cattle 1. 592 A comparison of three patterns of allocation for autumn-calving cows and heifers offered 593 grass silage ad libitum. Animal Science 39, 315-324

TAYLOR, W. \& LEAVER, J. D. (1984b) Systems of concentrate allocation for dairy cattle 2.

596 A comparison of two patterns of allocation for autumn-calving cows offered two qualities of

597 grass silage ad libitum. Animal Scienc 39, 315-324

WILLIAMS, E. J., FISCHER, D. P., PFEIFFER, D. U., ENGLAND, G. C. W., NOAKES, D. 600 E., DOBSON, H., \& SHELDON, I. M. (2005) Clinical evaluation of postpartum vaginal 601 mucus reflects uterine bacterial infection and the immune response in cattle. Theriogenology $60263,102-117$

603

604 YOUNG, H. A. \& HARDY, K. J. (1995) Role of interferon-gamma in immune cell

605

606

607 
Table 1 Chemical composition of grass silage and concentrates offered during the study

\begin{tabular}{lcc}
\hline & Grass silage & Concentrate \\
\hline Oven DM $(\mathrm{g} / \mathrm{kg})$ & 298 & 872 \\
$\mathrm{VCODM}^{1}(\mathrm{~g} / \mathrm{kg})$ & 314 & - \\
$\mathrm{pH}$ & 3.83 & - \\
Ammonia nitrogen $(\mathrm{g} / \mathrm{kg}$ total N) & 78 & \\
Composition of DM $(\mathrm{g} / \mathrm{kg})$ & & 180 \\
Crude protein & 159 & - \\
Ethanol & 18.4 & - \\
Propanol & 0.8 & - \\
Lactic acid & 126 & - \\
Acetic acid & 19.2 & - \\
Propionic acid & 0.33 & - \\
n-Butyric acid & 1.04 & 152 \\
I-Valeric & 0.17 & 303 \\
Acid detergent fiber & 291 & 73 \\
Neutral detergent fiber & 486 & 17.9 \\
Ash & 103 & \\
Gross energy (MJ/kg DM) & 18.3 & - \\
Metabolisable energy $(\mathrm{MJ} / \mathrm{kg} \mathrm{DM})$ & $11.6^{2}$ & \\
\hline
\end{tabular}

${ }^{1}$ VCODM, volatile corrected oven dry matter

${ }^{2}$ Predicted using Near Infrared Reflectance Spectroscopy

${ }^{3}$ Calculated from 'standard values' 
Table 2 Summary of the main effects of concentrate allocation strategy on total dry matter intake, milk yield, milk constituents, milk constituent yield, and bodyweight, during the first $140 \mathrm{~d}$ of lactation

\begin{tabular}{lcccc}
\hline & \multicolumn{2}{c}{ Concentrate Allocation Strategy } & & \\
\cline { 2 - 3 } & Feed-to-yield & Total-mixed-ration & SED $^{\mathbf{1}}$ & P-value \\
\hline Total dry matter intake (kg/d) & 22.2 & 22.4 & 0.31 & 0.773 \\
Concentrate dry matter intake (kg/d) & 11.7 & 11.5 & 0.25 & 0.714 \\
Milk yield (kg/d) & 38.0 & 39.3 & 0.95 & 0.326 \\
Milk fat (g/kg) & 42.8 & 42.9 & 0.46 & 0.882 \\
Milk protein (g/kg) & 32.9 & 32.4 & 0.31 & 0.258 \\
Fat + Protein yield (kg/d) & 3.0 & 3.1 & 0.09 & 0.420 \\
Mean Bodyweight (kg) & 623 & 621 & 4.9 & 0.782 \\
Bodyweight loss to nadir (kg) & 43 & 33 & 4.2 & 0.088 \\
Mean energy balance (MJ/cow per d) & -21.4 & -25.5 & 5.26 & 0.426 \\
\hline
\end{tabular}

${ }^{1} \mathrm{SED}$, standard error of the difference 
Table 3 Effects of concentrate allocation strategy on serum biochemistry and blood haematology during the first $140 \mathrm{~d}$ of lactation (mean of samples taken at weeks 2, 4, 6, 8, 10, 12, 16 and 20 postpartum)

\begin{tabular}{|c|c|c|c|c|c|c|}
\hline & \multirow{2}{*}{\multicolumn{2}{|c|}{$\begin{array}{c}\text { Concentrate Allocation } \\
\text { Strategy }\end{array}$}} & \multirow[b]{3}{*}{ SED $^{1}$} & \multirow{2}{*}{\multicolumn{3}{|c|}{ P-value }} \\
\hline & & & & & & \\
\hline & $\begin{array}{l}\text { Feed-to- } \\
\text { yield }\end{array}$ & $\begin{array}{c}\text { Total-mixed- } \\
\text { ration }\end{array}$ & & Treatment $^{2}$ & Time $^{3}$ & $\begin{array}{c}\text { Treatment }^{2} \\
\times \text { Time }^{3}\end{array}$ \\
\hline \multicolumn{7}{|l|}{ Biochemistry parameters } \\
\hline Glucose (meq/L) & 3.62 & 3.67 & 0.036 & 0.227 & $<0.001$ & 0.891 \\
\hline NEFA (meq/L) & 0.33 & 0.29 & 0.017 & 0.028 & $<0.001$ & 0.697 \\
\hline $\mathrm{BHB}(\mathrm{mM})$ & 0.44 & 0.46 & 0.022 & 0.379 & $<0.001$ & 0.271 \\
\hline Albumin $(\mathrm{g} / \mathrm{L})$ & 29.6 & 30.6 & 0.56 & 0.055 & 0.002 & 0.304 \\
\hline Globulin $(\mathrm{g} / \mathrm{L})$ & 40.3 & 39.2 & 1.41 & 0.583 & 0.247 & 0.306 \\
\hline Total protein $(\mathrm{g} / \mathrm{L})$ & 69.9 & 69.8 & 1.34 & 0.935 & 0.012 & 0.247 \\
\hline Urea $(\mathrm{mM})$ & 3.45 & 3.55 & 0.117 & 0.306 & $<0.001$ & 0.326 \\
\hline GLDH (U/L) & 66.1 & 53.8 & 10.34 & 0.444 & 0.019 & 0.064 \\
\hline \multicolumn{7}{|l|}{ Haematology Parameters ${ }^{4}$} \\
\hline Red Cell Count $\left(\times 10^{12} / \mathrm{L}\right)$ & 5.91 & 6.07 & 0.153 & 0.274 & 0.763 & 0.236 \\
\hline Haemaglobin $(\mathrm{g} / \mathrm{L})$ & 94.5 & 99.0 & 1.96 & 0.009 & 0.359 & 0.332 \\
\hline Packed Cell Volume (L/L) & 0.30 & 0.31 & 0.006 & 0.018 & 0.486 & 0.151 \\
\hline White Cell Count $\left(\mathrm{x} 10^{9} / \mathrm{L}\right)$ & 6.61 & 6.45 & 0.322 & 0.859 & $<0.001$ & 0.424 \\
\hline Lymphocyte (\%) & 72.7 & 76.3 & 1.68 & 0.020 & 0.005 & 0.571 \\
\hline Neutrophil (\%) & 24.6 & 21.1 & 1.63 & 0.018 & 0.008 & 0.507 \\
\hline \multicolumn{7}{|l|}{ Immunological parameters ${ }^{4}$} \\
\hline Haptoglobin $(\mathrm{mg} / \mathrm{mL})$ & 0.86 & 0.95 & 0.089 & 0.356 & 0.495 & 0.221 \\
\hline Interferon gamma $(\mathrm{ng} / \mathrm{mL})$ & 12.9 & 10.6 & 1.087 & 0.115 & 0.959 & 0.455 \\
\hline
\end{tabular}

NEFA $=$ nonesterified fatty acid, $\mathrm{BHB}=$ beta-hydroxybutryrate, GLDH $=$ glutamate dehydrogenase

${ }^{1} \mathrm{SED}$, standard error of the difference for treatment

${ }^{2}$ Concentrate allocation strategy

${ }^{3}$ Weeks postpartum

${ }^{4}$ Measured on a sub-group of 17 and 20 from the feed-to-yield and total-mixed-ration treatments, respectively 
Table 4 Summary of significant relationships $(\mathrm{P}>0.05)$ identified between energy balance and NEFA, BHB, glucose, WCC, neutrophil \%, lymphocyte \%, IFN- $\gamma$ and Hp, for cows offered concentrates by either a feed-to-yield or total-mixed-ration strategy (mean data for the study period and for weeks 6 to 10 of lactation)

\begin{tabular}{lccc}
\hline Equation & Treatment & $\mathbf{R}^{\mathbf{2}}$ & P value \\
\hline $\begin{array}{l}\text { Mean data for study period } \\
\mathrm{EB}=16.95-115.1 \mathrm{NEFA}\end{array}$ & $\begin{array}{c}\text { Feed-to-yield } \\
\text { EB }=8.77-115.1 \mathrm{NEFA}\end{array}$ & 0.196 & $<0.001$ \\
$\mathrm{~EB}=-94.1+10.3 \mathrm{WCC}$ & 1 & 0.258 & $<0.001$ \\
$\begin{array}{l}\text { Mean data for weeks 6 to 10 postpartum } \\
\mathrm{EB}=-3.61-76.3 \mathrm{NEFA}\end{array}$ & 1 & & \\
$\mathrm{~EB}=12.20-92.3 \mathrm{BHB}$ & 1 & 0.094 & 0.005 \\
$\mathrm{~EB}=-109.20+11.4 \mathrm{WCC}$ & 1 & 0.071 & 0.013 \\
\hline
\end{tabular}

${ }^{1}$ Both treatments described by a common equation

$\mathrm{NEFA}=$ nonesterified fatty acid, $\mathrm{BHB}=$ beta-hydroxybutryrate, $\mathrm{WCC}=$ white cell count 
Table 5 Summary of significant relationships $(P>0.05)$ identified between energy corrected milk yield (ECMY) and NEFA, BHB, glucose, WCC, neutrophil \%, lymphocyte \%, IFN- $\gamma$ and Hp, for cows offered concentrates by either a feed-to-yield or total-mixed-ration strategy (mean data for the study period and for weeks 6 to 10 of lactation)

\begin{tabular}{llll}
\hline Equation & Treatment & $\mathbf{R}^{2}$ & P value
\end{tabular}

\section{Mean data for study period}

$\begin{array}{llll}\mathrm{ECMY}=34.66+16.46 \mathrm{NEFA} & 1 & 0.069 & 0.015 \\ \mathrm{ECMY}=33.55+13.96 \mathrm{BHB} & 1 & 0.050 & 0.033\end{array}$

$\mathrm{ECMY}=53.20-2.10 \mathrm{WCC} \quad$ Feed-to-yield

$\mathrm{ECMY}=47.12-0.72 \mathrm{WCC} \quad$ Total-mixed-ration

$0.179 \quad 0.013$

\section{Mean data for weeks 6 to 10 postpartum}

\begin{tabular}{|c|c|c|c|}
\hline $\mathrm{ECMY}=20.81+51.7 \mathrm{BHB}$ & Feed-to-yield & \multirow{2}{*}{0.178} & \multirow{2}{*}{$<0.001$} \\
\hline $\mathrm{ECMY}=33.33+19.23 \mathrm{BHB}$ & Total-mixed-ration & & \\
\hline $\mathrm{ECMY}=58.93-2.39 \mathrm{WCC}$ & 1 & 0.234 & 0.001 \\
\hline
\end{tabular}

\footnotetext{
${ }^{1}$ Each treatment described by separate equations
}

NEFA $=$ nonesterified fatty acid, $\mathrm{BHB}=$ beta-hydroxybutryrate, $\mathrm{WCC}=$ white cell count 
Table 6 Effects of concentrate allocation strategy on the probability (and standard error) of obtaining a mucus score of $0,1, \geq 2$ on wk 2,3 , and 4 ( \pm 3 d) of lactation

\begin{tabular}{lcccc}
\hline & \multicolumn{3}{c}{ Mucus score } & \multirow{2}{*}{ P value } \\
\cline { 2 - 4 } & \multicolumn{1}{c}{$\mathbf{0}$} & $\mathbf{1}$ & $\mathbf{2}$ & \\
\hline Week 2 & & & \\
Feed-to-yield & $0.19(0.150)$ & $0.40(0.136)$ & $0.40(0.131)$ & \\
$\quad$ Total-mixed-ration & $0.09(0.171)$ & $0.30(0.138)$ & $0.61(0.107)$ & 0.080 \\
Week 3 & & & & \\
Feed-to-yield & $0.39(0.141)$ & $0.34(0.143)$ & $0.26(0.156)$ & \\
Total-mixed-ration & $0.54(0.114)$ & $0.30(0.144)$ & $0.17(0.152)$ & \\
Week 4 & & & 0.199 \\
Feed-to-yield & $0.63(0.105)$ & $0.28(0.150)$ & $0.08(0.159)$ & \\
Total-mixed-ration & $0.59(0.110)$ & $0.31(0.140)$ & $0.10(0.170)$ & 0.725 \\
\hline
\end{tabular}


Table 7 Effects of concentrate allocation strategy on the percentage of cows treated for a number of health problems, and on somatic cell count and somatic cell score during the first 140 $\mathrm{d}$ of lactation

\begin{tabular}{|c|c|c|c|c|}
\hline & \multicolumn{2}{|c|}{ Concentrate Allocation Strategy } & \multirow[b]{2}{*}{ SED $^{1}$} & \multirow[b]{2}{*}{ P-value } \\
\hline & Feed-to-yield & Total-mixed-ration & & \\
\hline \multicolumn{5}{|l|}{ Percentage of cows treated for: ${ }^{3}$} \\
\hline Clinical Mastitis & 31 & 36 & 7.8 & 0.617 \\
\hline Lameness & 28 & 14 & 6.6 & 0.144 \\
\hline Respiratory problems & 14 & 8 & 5.2 & 0.451 \\
\hline Digestive disorders & 22 & 8 & 5.8 & 0.096 \\
\hline Somatic Cell Count $(1000 / \mathrm{mL})$ & 91 & 61 & & \\
\hline Somatic Cell Score ${ }^{2}$ & 10.82 & 10.45 & 0.23 & 0.125 \\
\hline
\end{tabular}

${ }^{1}$ SED, standard error of the difference for treatment

${ }^{2}$ Natural logarithm $\left(\log _{e}\right)$ of somatic cell count

${ }^{3}$ Percentage of cows with at least one incidence 